\title{
Analysis of The Use of The Bebunge Application Using End-user Computing Satisfaction Model
}

\author{
Resad Setyadi ${ }^{*}$, Muhammad Hamzah Baqi ${ }^{1}$ \\ 1Information System, Faculty of Informatics, Institut Teknologi Telkom Purwokerto, Indonesia \\ *Corresponding Author: resad@ittelkom-pwt.ac.id
}

\begin{abstract}
INTISARI
Pemkab Bekasi sudah memiliki aplikasi pelayanan terpadu yaitu Bebunge atau Bekasi Nyambung Bae. Aplikasi ini merupakan bagian awal dari rencana kabupaten Bekasi untuk mempersiapkan Bekasi menjadi Kota Cerdas. Melalui aplikasi Bebunge, warga Bekasi bisa mendapatkan informasi kebutuhan penduduk. Namun sejauh mana kepuasan masyarakat Bekasi terhadap aplikasi Bebunge sehingga pemerintah Bekasi bisa mendapatkan evaluasi penggunaan aplikasi dengan melihat tingkat kepuasan pengguna. Penelitian ini menganalisis tingkat kepuasan pengguna aplikasi Bebunge dengan menggunakan model End User Computing Satisfaction (EUCS). Metode analisis kuesioner menggunakan analisis statistik inferensial dengan media Smart PLS. Berdasarkan pedoman tingkat kepuasan, hasil penelitian menunjukkan bahwa jika tingkat kepuasan masyarakat Bekasi menurut analisis Customer Satisfaction Index (CSI) maka aplikasi Bebunge memiliki rating kepuasan sebesar 81,54 . Nilai tersebut diatas $80 \%$ yang artinya masyarakat Bekasi sangat puas menggunakan aplikasi bebunge pada awal-pertengahan tahun 2020-an. Rekomendasi dari aplikasi Bebunge adalah diperlukan tambahan fitur untuk mengakses lowongan kerja, informasi status terbaru update COVID-19 di Bekasi, dan Update status zona COVID-19 di Bekasi. Kontribusi dari penelitian ini adalah untuk meningkatkan fungsionalitas aplikasi Bebunge bagi masyarakat Bekasi. Kontribusi kedua dari penelitian ini menjadi referensi bagi peneliti dari subdomain smart city yaitu smart society.
\end{abstract}

Kata kunci: Bekasi, bebunge, end-user computing satisfaction, smart pls, satisfaction.

\begin{abstract}
The Bekasi district Government already has an integrated service application, namely Bebunge or Bekasi Nyambung Bae. This application is the beginning of the Bekasi district plan to prepare Bekasi for a Smart City. Through the Bebunge application, Bekasi residents can get information for population needs. However, to what extent is the satisfaction of Bekasi society with the Bebunge application so that the Bekasi government can get an evaluation of application usage by looking at the level of user satisfaction. This study analyzes the level of user satisfaction of the Bebunge application using the End User Computing Satisfaction (EUCS) model. The questionnaire analysis method uses inferential statistical analysis with Smart PLS media. Based on the guidelines for the level of satisfaction, the study results show that if the satisfaction level of Bekasi society according to the Customer Satisfaction Index (CSI) analysis, the Bebunge application has a satisfaction rating of 81.54. This value is above $80 \%$, which means that the Bekasi community is very satisfied using the bebunge application in the early-mid-2020s. The recommendation for the Bebunge application is that additional features are needed to access job vacancies, information on the latest status updates for COVID-19 in Bekasi, and an Update on the status of the COVID-19 zone in Bekasi. The contribution of this study is to improve the functionality of the Bebunge application for the Bekasi society. The second contribution of this study is to become a reference for researchers from the subdomain of smart cities, namely smart society.
\end{abstract}

Keywords: Bekasi, bebunge, end-user computing satisfaction, smart pls, satisfaction.

\section{INTRODUCTION}

The Bekasi District Government has officially launched an integrated service application, namely
Bebunge or Bekasi Nyambung Bae. Regent Eka Supria Atmaja at the launch of Bebunge at the Bekasi district Communication, Informatics, 
Encryption, and Statistics Office, Thursday, March 5 , 2020. It is a breakthrough whose aim is to make it easy for Bekasi district residents to get services.

The Bekasi community can download the Bebunge application via the Android system. Through this application, Bekasi society can obtain information such as health and matters related to population data. Bebunge helps to connect with several regional or service organizations. The Department of Communication and Information, the Health Service, Regional General Hospitals, the Regional Disaster Management Agency, the Fire Service to the Population, and Civil Registration Service. Internet technology has made it easier for users to communicate and find various information with the help of Bebunge. The presence of the Internet makes it easy to get information [1]. It is easy to determine how the existing system is successful; it needs evaluation to prove it.

One method to determine the success of a system is DeLone \& McLean [2]. This method formulates that the success of information systems consists of six factors, namely, System Quality, Information Quality, Service Quality, System Use, User Satisfaction, and System Benefits. While measuring user satisfaction, there is a measurement instrument that can be used to analyze application innovation, namely End-User Computing Satisfaction (EUCS) [3]. A comparative study between the EUCS and UIS instruments found that the EUCS method was more valuable than the UIS method [4]. The importance of mobile application display is to build a positive image in the eyes of consumers so that it can gain consumer confidence and create a pleasant atmosphere for users to search for information until emotional appeal emerges [5]. It encourages researchers to evaluate the level of satisfaction of Bekasi residents with the Bebunge application to satisfy users during the COVID-19 pandemic situation better.

\section{METHOD}

Study data comes from direct data from the research object, which gets a questionnaire form and fills out the form [6]. The nature of the questionnaire data is closed; it has been given alternative answers with the target respondents from the Bekasi district government employees, the Bekasi community, and the immigrant community. The study variables were under the EUCS model instrument: content, accuracy, format, ease of use, and timeliness. Figure 1 illustrates the EUCS model instrument.

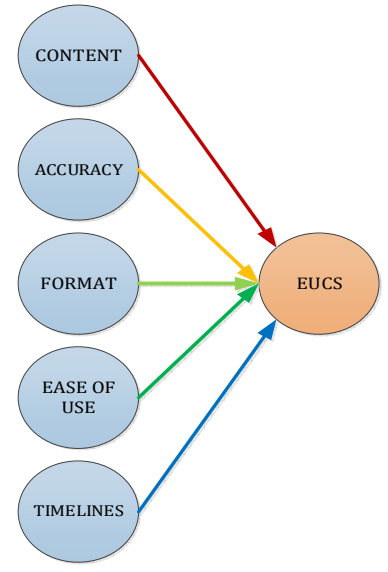

Figure 1. EUCS Model

The respondent questionnaire data is adjusted to the questions in the EUCS model. It is the results of the answers that served as guidelines for the responses from Bekasi residents. Table 1 describes the description of the indicator questions for each of the EUCS model variables.

Table 1. The Description EUCS Indicators

\begin{tabular}{ll}
\hline Var & \multicolumn{1}{c}{ Indicator } \\
\hline CON & 1. The information in the Bebunge application is \\
according to the needs of the Bekasi society. \\
2. The information on the Bebungee application is \\
easy to understand \\
3. The information in the Bebunge application is \\
complete \\
4. The information on the Bebunge app is obvious \\
1. The accuracy of the information from the \\
Bebunge application is correct and accurate \\
2. It is appropriate that the link, when clicked, \\
always displays the relevant web page.
\end{tabular}

FOR 1. The color display design of the Bebunge app is attractive.

2. The design of the Bebunge application layout is attractive.

3. The menu structure display design of the Bebunge application is complete.

E0U 1. The Bebunge app is easy to use

2. The Bebunge application is easily accessible from anywhere and anytime.

TIM 1. The Bebunge application provides the information you need quickly.

2. The Bebunge application always displays the latest information.

EUC 1. People are satisfied with the features of the Bebunge application

2. The community is satisfied with the response to the Bebunge application service

3. The community is satisfied with the performance response of the Bebunge application system

Sampling was determined using a stratified random sampling technique [7]. The sample of respondents is 80 people, using the Slovin formula 
with a confidence level of $95 \%$, which is divided into three groups of users, namely employees (15 people), Bekasi society (55 people), and newcomers (10 people). The rules for filling out the questionnaire by respondents use a Likert scale [8]. The Likert scale of the reference for this study is shown in Table 2 .

\begin{tabular}{|c|c|}
\hline Scale & definition \\
\hline 1 & Very agreed \\
\hline 2 & agreed \\
\hline 3 & moderate \\
\hline 4 & Disagreed \\
\hline 5 & Very Disagreed \\
\hline
\end{tabular}

To determine the level of satisfaction of the Bekasi community as a user of the Bebunge application, this study uses the conversion of satisfied and dissatisfied statements on the user questionnaire into five levels of satisfaction. The satisfaction level of the application user is shown in Table 3.

Table 3. levels of Satisfaction

\begin{tabular}{cc}
\hline Range & Level of Satisfaction \\
\hline $80 \%<$ LOS $\leq 100 \%$ & Very satisfied \\
$60 \%<$ LOS $\leq 80 \%$ & satisfied \\
$40 \%<$ LOS $\leq 60 \%$ & hesitant \\
$20 \%<$ LOS $\leq 40 \%$ & Dissatisfied \\
$0 \%<$ LOS $\leq 20 \%$ & Very Dissatisfied \\
\hline
\end{tabular}

After getting the questionnaire results, the next step was to test the validity and reliability with Smart PLS media [9]. Validity calculations can also use equation (1) to calculate the value of r. A questionnaire statement is said to be valid if $r$ count $>\mathrm{r}$ table.

$$
\sigma=\frac{n \sum-\left(\sum x\left(\sum y\right)\right)}{\sqrt{\left\{\left(n \sum x^{2}-\left(\sum x\right)^{2}\right)\right\}\left\{n \sum y^{2}-\sum y^{2}\right\}}}
$$

The Cronbach alpha (CA) value refers to a questionnaire set in reliable or reliable conditions [10]. A valid questionnaire statement and declared trustworthy if the CA is valued $>0.90$, the reliability is perfect. If the CA is between $0.70-0.90$, the reliability is high. If $\mathrm{CA}$ is $0.50-0.70$, then the reliability is moderate.

\section{RESULTS AND DISCUSSION}

The validity of the questionnaire instrument is using 40 respondents from a total of 80 . The result of an $r$ table with 16 questions and 40 respondents is 0.312 . The questionnaire provides a validity test, as shown in Table 4.

\begin{tabular}{cccccccc}
\multicolumn{2}{l}{ Table 4. Instrument test of validity } \\
\hline No & $\begin{array}{c}\mathbf{r} \\
\text { count }\end{array}$ & No & $\begin{array}{c}\mathbf{r} \\
\text { count }\end{array}$ & No & $\begin{array}{c}\mathbf{r} \\
\text { count }\end{array}$ & No & $\begin{array}{c}\mathbf{r} \\
\text { count }\end{array}$ \\
\hline 1 & .706 & 5 & .893 & 9 & .846 & 13 & .729 \\
2 & .802 & 6 & .936 & 10 & .681 & 14 & .648 \\
3 & .781 & 7 & .912 & 11 & .911 & 15 & .791 \\
4 & .793 & 8 & .914 & 12 & .724 & 16 & .742 \\
\hline
\end{tabular}

The reliability test of the questionnaire instrument looks at the results of using the Cronbach alpha (CA) test of Smart PLS. Reliability test as shown in Figure. 1

\begin{tabular}{l|r|r|r|r|} 
& Cronbach's Alpha & rho_A & Composite Reliability & Average Variance Extracted (AVE) \\
\hline ACC & 0.823 & 0.864 & 0.918 & 0.848 \\
\hline CON & 0.827 & 0.838 & 0.885 & 0.660 \\
\hline EOU & 0.848 & 0.849 & 0.929 & 0.868 \\
\hline EUC & 0.879 & 0.880 & 0.925 & 0.805 \\
\hline FOR & 0.873 & 0.880 & 0.923 & 0.799 \\
\hline TIM_ & 0.811 & 0.811 & 0.914 & 0.841 \\
\hline & Figure 1 CA test of Smart PLS \\
\hline
\end{tabular}

The analysis results using Smart PLS media against the EUCS model are as shown in Fig. 2.

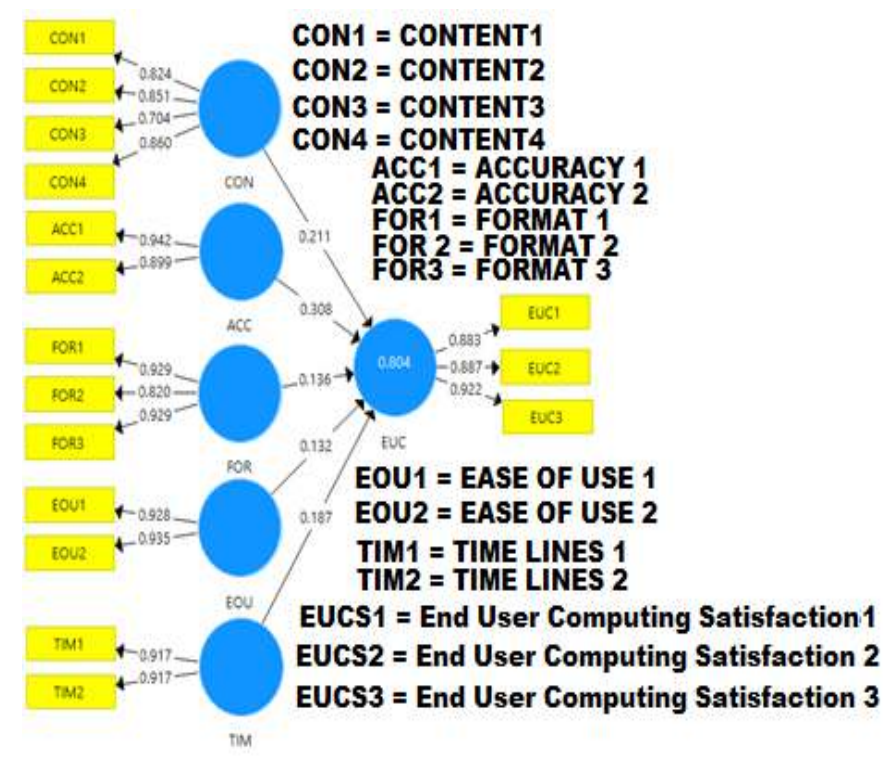

Figure 2 EUCS Model Analysis Using Smart PLS 
Analysis of the satisfaction level of the Bebunge application users uses the calculation of the Customer Satisfaction Index (CSI) [11]. The satisfaction level of Bebunge application users needs to find the Mean Satisfaction Score (MSS) and Mean Importance Score (MIS).

MSS $=\frac{n \sum_{1}^{n} \text { value scale }}{n}$

MSS = respondents who use the Bebunge application

$\mathrm{n}=$ number of respondent

$M I S=\frac{m \sum_{1}^{m} \text { value scale }}{m}$

MIS = respondents who have expectation data of the Bebunge application

$\mathrm{m}=$ number of respondent

$\mathrm{WF}=$ Weighting Factors, which is a function of the median importance of each attribute in the form of a percentage (\%) of the total median score of significance for all tested attributes

WS $=$ Weighted Score, which is a function of the median score of the satisfaction level of each attribute multiplied by the Weighting Factors (WF) of each detail.

MIS data from expectation data of the Bebunge application. Data from MSS comes from data from respondents who use the Bebunge application. MIS table and MSS table as shown in Table 5 and Table 6.

Table 5. Mean Satisfaction Score

\begin{tabular}{ccllll}
\hline \multirow{2}{*}{ Indicator } & \multicolumn{4}{c}{ Likert Scale } & \multirow{2}{*}{ MSS } \\
& $\mathbf{2}$ & $\mathbf{3}$ & $\mathbf{4}$ & $\mathbf{5}$ & \\
\hline CON1 & & 3 & 65 & 12 & 4.11 \\
CON2 & & 4 & 61 & 15 & 4.14 \\
CON3 & & 15 & 55 & 10 & 3.95 \\
CON4 & 6 & 59 & 16 & 4.13 \\
ACC1 & 1 & 68 & 11 & 4.13 \\
ACC2 & 6 & 63 & 11 & 4.06 \\
FOR1 & 7 & 61 & 12 & 4.05 \\
FOR2 & 5 & 61 & 14 & 4.11 \\
FOR3 & 13 & 65 & 12 & 3.99 \\
EOU1 & 8 & 62 & 10 & 4.03 \\
EOU2 & 4 & 65 & 11 & 4.09 \\
TIM1 & 8 & 61 & 11 & 4.04 \\
TIM2 & 8 & 61 & 11 & 4.04 \\
EUC1 & 1 & 68 & 11 & 4.13 \\
EUC2 & 1 & 68 & 11 & 4.13 \\
EUC3 & 2 & 66 & 12 & 4.13 \\
\hline
\end{tabular}

Table 6. Mean Importance Score

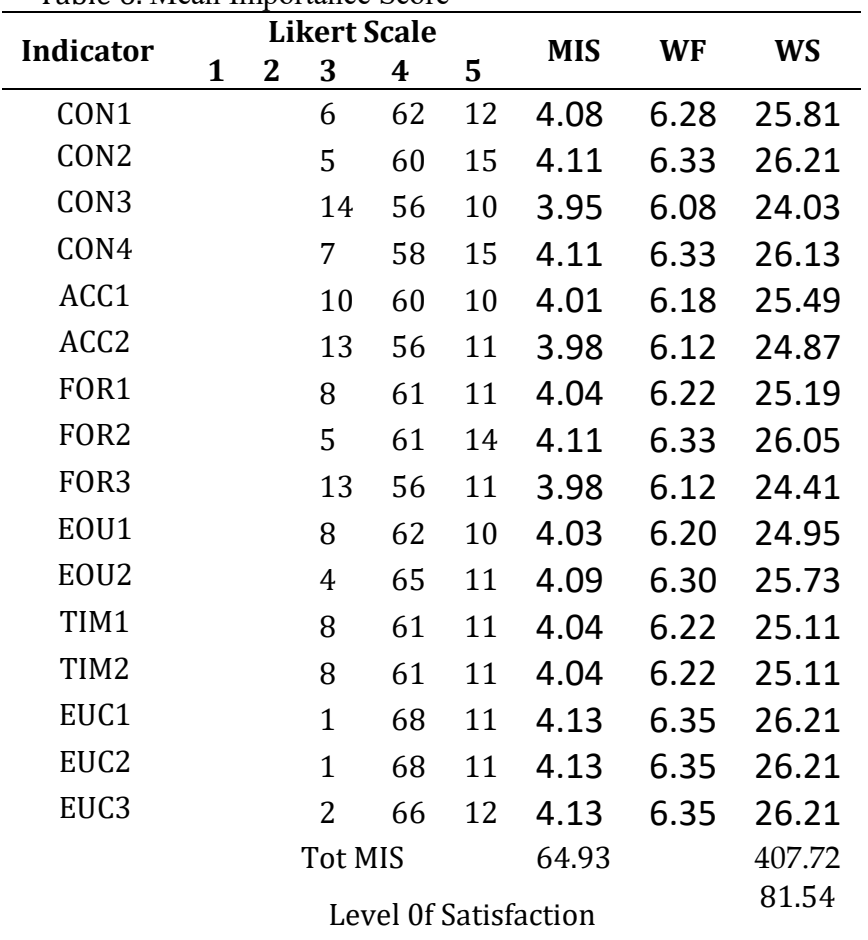

Based on data analysis, the number of respondents when testing the instrument did not use the entire sample, but only 40 of the total number of respondents with a random sampling of respondents as examiners of the questionnaire instrument [12]. The validity results for the instrument test were 16 questions, and 40 respondents were $r$ count $>$ from $r$ table, and the results were valid. The value of the $r$ table for 40 respondents is 0.312 , while the $r$ count has a value above the $r$ table. The reliability test of valid instruments using the SMART PLS [13]. The CR value is above 0.7 , which means that the questionnaire instrument is reliable for studying the satisfaction of the Bebunge application users. Based on the analysis of the model using Smart PLS, the final variable EUC value has a percentage of $80.4 \%$, meaning that the EUCS model with the existing questionnaire instrument can be a valid and reliable measuring tool. The satisfaction value of using the Bebunge application by the Bekasi community comes from the Customer Satisfaction Index (CSI) analysis of the questionnaire data [14]. The satisfaction level can be measured using a Likert and CSI scale [15]. According to the CSI analysis, the Bebunge application has a satisfaction rating of 81.54 . This value is above $80 \%$, which means that the Bekasi community is very satisfied using the bebunge application in the early-mid2020s. 


\section{CONCLUSION}

EUCS is a method of measuring the satisfaction level of Bebunge application usage by comparing the expectations and the reality of an information system. Overall evaluation of Bebunge application users from information based on user experience in using the application. The value of using the Bebunge application is very satisfying, with a value of $81.54 \%$. The standard is very satisfactory to be at least above $80 \%$. The existing recommendations for developing the Bebunge application software are the need for additional features to access job vacancies, information on the latest COVID-19 status updates in Bekasi, and updates on the status of the COVID-19 zone in Bekasi. The contribution of this study is the need to improve the functionality of the Bebunge application for the Bekasi community. The second contribution of this research is that this study can be a reference for researchers from the smart city sub-domain, namely the smart community.

\section{REFERENCES}

[1] S. Kaur and I. Singh, "A Survey Report on Security \& Challenges in Internet of Things A Survey Report on Security \& Challenges in Internet of Things," Int. Journal Comput. Sci. Trends Technol., vol. 4, no. January, pp. 330335, 2016.

[2] W. H. DeLone and E. R. McLean, Information Systems Success Measurement, vol. 2, no. 1. 2016.

[3] E. Domínguez-Escrig, F. F. M. Broch, R. Lapiedra, and R. Chiva, "Promoting radical innovation through end-user computing satisfaction," Ind. Manag. Data Syst., vol. 118, no. 8, pp. 1629-1646, 2018, DOI: 10.1108/IMDS-06-2017-0256.

[4] A. Fitriansyah and I. Harris, "Pengukuran Kepuasan Pengguna Situs Web Dengan Metode End User Computing Satisfaction (EUCS)," Query J. Sist. Inf., vol. 2, no. 1, pp. 18, 2018, [Online]. Available: http://jurnal.uinsu.ac.id/index.php/query/ article/view/1552.

[5] A. Tarute, S. Nikou, and R. Gatautis, "Mobile application-driven consumer engagement," Telemat. Informatics, vol. 34, no. 4, pp. 145156, 2017, DOI: 10.1016/j.tele.2017.01.006.

[6] C. Igwenagu, "Fundamentals of Research Methodology and Data Collection," $L$. Lambert Acad. Publ., no. June, p. 4, 2016,
[Online]. Available: https://www.researchgate.net/publication/ 303381524_Fundamentals_of_research_met hodology_and_data_collection.

[7] T. D. Nguyen, M. H. Shih, D. Srivastava, S. Tirthapura, and B. Xu, Stratified random sampling from streaming and stored data, no. 0123456789. Springer US, 2020.

[8] B. Weijters, K. Millet, and E. Cabooter, "Extremity in horizontal and vertical Likert scale format responses. Some evidence on how visual distance between response categories influences extreme responding," Int. J. Res. Mark., vol. 38, no. 1, pp. 85-103, 2021, DOI: 10.1016/j.ijresmar.2020.04.002.

[9] B. H. Khoi and N. Van Tuan, "Using SmartPLS 3.0 to analyze internet service quality in Vietnam," Stud. Comput. Intell., vol. 760, pp. 430-439, 2018, DOI: 10.1007/978-3-31973150-6_34.

[10] B. Sharma, "A focus on reliability in developmental research through Cronbach's Alpha among medical, dental and paramedical professionals," Asian Pacific J. Heal. Sci., vol. 3, no. 4, pp. 271-278, 2016, DOI: 10.21276/apjhs.2016.3.4.43.

[11] A. Justitia, R. Semiati, and N. R. Ayuvinda, "Customer Satisfaction Analysis of Online Taxi Mobile Apps," J. Inf. Syst. Eng. Bus. Intell., vol. 5, no. 1, p. 85, 2019, doi: 10.20473/jisebi.5.1.85-92.

[12] K. S. Taber, "The Use of Cronbach's Alpha When Developing and Reporting Research Instruments in Science Education," Res. Sci. Educ., vol. 48, no. 6, pp. 1273-1296, 2018, DOI: $10.1007 / \mathrm{s} 11165-016-9602-2$.

[13] A. Kamis, R. A. Saibon, F. A. Nur Yunus, M. B. Rahim, L. M. Herrera, and P. L. Yturria Montenegro, "The SmartPLS analyzes approach in validity and reliability of graduate marketability instrument," Turkish J. Comput. Math. Educ., vol. 12, no. 3, pp. 829-841, 2021, doi: 10.17762/turcomat.v12i3.791.

[14] Y. C. Lee et al., "An empirical research on customer satisfaction study: a consideration of different levels of performance," Springerplus, vol. 5, no. 1, 2016, DOI: 10.1186/s40064-016-3208-z.

[15] R. Pardiyono and H. D. Puspita, "Measurement of Student Satisfaction Using Customer Satisfaction Index (CSI)," J. Res. Business, Econ. Educ., vol. 2, no. 6, pp. 1493-1499, 2020. 